\title{
An Analysis of the Biodiversity of Earthworms in Three Locations around Tiruchirappalli, Tamil Nadu, India
}

\author{
V. Senthil and R. Sivakami*
}

Department of Zoology, Arignar Anna Govt. Arts College, Musiri -621211, Tamil Nadu, India

*Corresponding author

\section{A B S T R A C T}

\begin{tabular}{|l|}
\hline Ke y w o r d s \\
$\begin{array}{l}\text { Earthworm population, } \\
\text { Tiruchirappalli, Tamil } \\
\text { Nadu }\end{array}$ \\
\hline Article Info \\
\hline $\begin{array}{l}\text { Accepted: } \\
\text { 20 August } 2018 \\
\text { Available Online: } \\
\text { 10 September } 2018\end{array}$ \\
\hline
\end{tabular}

\section{Introduction}

Earthworms are one of the most important fauna of ecosystems and they dominate the biomass of invertebrates in many soils of temperate and tropical regions of the world (Rai, 2017). They have attracted a lot of interest due to their beneficial effects in agriculture (Ebanasar et al., 2015). Earthworm feeding behaviour, burrowing and casting are vital in nutrient cycling and decomposition regulation (Larink et al., 2001; Dechaine et al., 2005).

India is a mega diverse country due to its unique location and diverse climatic conditions and as many as 418 species of earthworms have been identified in our country harbouring $11.1 \%$ of the global earthworm diversity (Mariappan et al., 2013). Out of the total of 3627 species of earthworms that has been identified throughout the globe (Reynolds, 1994).

As earthworms have variable effects on the physical, chemical and biological properties of the soil (Lee, 1985; Teng et al., 2013). They can be used as indicators of soil characteristics.

Literature reveals that earthworm studies in Tamil Nadu are scanty (Parthasarathi et al., 2015) and hence the present study was attempted in three locations of Tiruchirappalli District which is the midpoint of the whole Tamil Nadu State. 


\section{Materials and Methods}

Field survey was conducted in the three agricultural areas and available earthworm species were collected by hand sorting method by digging up the soil. Samples were taken from moist soils near the agricultural areas which had an excellent environment for earthworms.

The earthworm survey was carried out in three different places (Vathalai, Vellore and Musiri) within a radius eight kilometer distance of Tiruchirappalli district. The soil core was dug out and the warms were hand sorted according to the method described by Lewis and Taylor (1968). The worms were sorted according to their species and kept separately in polythene bags containing the mother soil taken from the collection site. Care was taken while digging so as to avoid damaging earthworms or killing them. The worms were preserved in $5-10 \%$ formalin solution following the method suggested by Julka (1993) in the laboratory.

\section{Collection of soil sample and analysis}

The soil from the agricultural areas were collected in polythene bags, numbered and taken to the laboratory for analysis. Physicochemical characteristics of the soil samples was done using standard methods. Soil $\mathrm{pH}$ was measured in 1:5 suspension of soil and distilled water using a $\mathrm{pH}$ meter (Jackson, 1973). Organic carbon and organic matter content was estimated by Walkley and Black method (1947) and total nitrogen content by Kjeldahl method (Jackson, 1973).

Phosphorous and potassium were analysed by following methods Tandon (1993). Soil temperature was measured by using digital thermometer and the moisture content was found out by keeping the fresh soil sample in hot air oven at $105^{\circ} \mathrm{C}$ until getting constant weight.

\section{Results and Discussion}

The results of the various physico-chemical variables that were analysed in the soil samples of the three localities are presented in Table 1. While the various species of earthworms that were isolated from the three localities are presented in Table 2. As evident from Table 2, a total of 11 species of earthworms belonging to 9 genera could be identified. As far as Musiri (Site-1) was concerned, a total of eight earthworm species belonging to seven genera could be identified out of this, Polypheritima elongata was unique to this site as it was absent in the other two localities. With regard to the second location (Vathalai), a total of 9 species of earthworms belonging to genera could be identified. It also had an unique species (Pontoscolex corethrurus) which was absent in the other two sites. In the third location (Vellore), a total of five species of earthworms belonging to five genera could be identified. However, it did not record any unique species.

A comparison between the three localities reveals that the highest diversity was recorded in Vathalai ( 9 species) followed by Musiri ( 8 species) and Vellore (5 species). Among the 11 species, two species (Dichogaster bolani and Lampito mauritii) was found to be common to all the three sites. A comparison between Musiri and Vathalai sites reveals that six species $(D$. bolani, $P$. excavatus, $L$. marutii, E. eugenia, $O$. serrata and $D$. willsi) were common to both while one species $(P$. elongata) were unique to Musiri and three species ( $P$. corethrurus, D. lamella and $M$. houlleti) were unique to Vathalai. A comparison between Musiri and Vellore localities reveals that four species were common to both systems ( $D$. bolam, $P$. sansibaricus, L. mauritii, E. eugenia) and four species were unique to Musiri ( $P$. excavatus, $P$. elongata, $O$. serrata and $D$. willsi) and one species was unique to Vellore (D. lamella). 
Table.1 Physico-chemical and climatic condition of the study sites of Tiruchirappalli

\begin{tabular}{|c|c|c|c|c|}
\hline S. No. & Ecological Parameters & Mukkombu & Velloree & Musuri \\
\hline 1. & Soil texture & Clay with litter organic & Clay \& Loam with little organic & Clay and leaf litter \\
\hline 2. & $\mathrm{pH}$ & $7.4 \pm 0.24$ & $7.8 \pm 4.76$ & $7.9 \pm 0.32$ \\
\hline 3. & Moisture (\%) & $42.0 \%$ & $30.0 \%$ & $38.0 \%$ \\
\hline 4. & Soil Temperature $\left({ }^{\circ} \mathrm{C}\right)$ & $22 \pm 0.86$ & $24 \pm 0.36$ & $23 \pm 0.64$ \\
\hline 5. & Organic Carbon (\%) & $5.86 \pm 0.72$ & $1.39 \pm 0.34$ & $3.42 \pm 0.72$ \\
\hline 6. & Nitrogen $(\%)$ & $0.42 \pm 0.64$ & $0.30 \pm 0.46$ & $0.34 \pm 0.60$ \\
\hline 7. & Phosphorus (kg ha ${ }^{-1}$ ) & $28.4 \pm 0.50$ & $20.6 \pm 0.78$ & $22.8 \pm 0.38$ \\
\hline 8. & Potassium (kg ha $\left.{ }^{-1}\right)$ & $86.7 \pm 0.64$ & $70.4 \pm 0.84$ & $74.6 \pm 0.72$ \\
\hline
\end{tabular}

Table.2 Cauvery Delta, Mukkombu, Musiri

\begin{tabular}{|c|c|c|c|c|c|c|c|}
\hline $\begin{array}{l}\text { S. } \\
\text { No. }\end{array}$ & Order & Family & Genera & Species & Musiri & $\begin{array}{c}\text { Vathalai } \\
\text { (Mukkombu) }\end{array}$ & Vellore \\
\hline \multirow[t]{8}{*}{1.} & \multirow[t]{8}{*}{ Haplotaxida } & Octochaetidae & Dichogaster & Dichogasterbolaui & + & + & + \\
\hline & & Glossocolecida & Pontoscolex & Pontoscolexcorethrurus(Muler) & - & + & - \\
\hline & & \multirow[t]{3}{*}{ Megascolecide } & \multirow[t]{2}{*}{ Perionyx } & Perionyx excavatus (Muler) & + & + & - \\
\hline & & & & Perionyx sansibaricus(Muler) & + & - & + \\
\hline & & & Lampito & Lampitomauritii (Knberg) & + & + & + \\
\hline & & \multirow[t]{2}{*}{ Eudrilidae } & Eudrilus & Eudriluseugenia(Kinbeg) & + & + & + \\
\hline & & & Polypheretima & Polypheretimaelongata & + & - & - \\
\hline & & Octochaetidae & Octochaetonona & Octochaetona serrata (Gates) & + & + & - \\
\hline \multirow[t]{3}{*}{2.} & \multirow[t]{3}{*}{ Moniligastrida } & \multirow[t]{3}{*}{ Moniligastridae } & \multirow[t]{3}{*}{ Drawida } & Drawidawillsi (Michaelsen) & + & + & _- \\
\hline & & & & Drawida lamella (Gates) & - & + & + \\
\hline & & & & Metaphirehoulleti & - & + & - \\
\hline
\end{tabular}


A comparison between Vathalai and Vellore reveals that four species (D. bolani, $L$. mauritii, E. eugenia and D. lamella) were common to both while five species ( $P$. corethrurus, $P$. excavatus, $O$. serrata, $D$. willsi and M.loulleti) were unique to Vathalai and one species ( $P$. sansibaricus) was unique to Vellore.

Literature reveals that Fragoso et al., (1999) reported that the number of species in a given earthworm community is the easiest method of species diversity and usually ranges from 3-17 in tropical and temperate ecosystems. This report is in line with the present observations as the three localities, showed species diversity ranging from 6-10.

Parthasarathi et al., (2015) while studying the earthworm populations in two agro systems in Tamil Nadu also reported comparable results. Deepthi and Kathireswari (2016) while studying earthworm diversity in Kozhikode in Kerala reported the presence of six species of earthworms which is also in line with the present observations.

In the present study, maximum diversity was recorded in Vathalai region. As perusal of the physico-chemical variables reveals that maximum nutrient content was recorded in this region. This could be the reason why maximum diversity of earthworms was noticed in this region. Deepthi and Kathireswari (2016) also suggested that maximum earthworms are found in places where nitrogen content is highest.

This appears to be line in the present study also. They also opined that L. mauritii is usually observed in polluted area as it has high adaptability and natural immunity to withstand against various soil and climatic conditions. This might be the reason why it was recorded in all the three locations in the present study.
As to the difference in diversity noticed in the three locations, literature reveals that diversity of earthworms in India is primarily due to its location, complex topography and variation in climate. In addition changes in land use pattern, increasing trend in urbanization, intensification of agriculture and pressure on native resources and habitats could also affect earthworm population (Parthasarathi et al., 2015). Capowiecz (2000) suggested that earthworm communities are the result of interaction between species and sensitivity to ecological factor while Jhulka (2014) suggested that the distinction of native vegetation and changes in land use pattern affect the composition and structure of earthworm species in different agro-climatic regions. The above recommendations hold good in the present study also.

\section{References}

A survey on the diversity and distribution of earthworms in higher altitudes of Nilgiris (Tamil Nadu, India) during monsoon seasons. Int. J. Curr. Res., 7: 23007-23010.

Capowiecz, Y. (2000). Differences in burrowing behaviour and spatial interaction between the two earthworm species. Aporrectodea nocturna and Allolobophora chlorotica. Biol. Fert. Soils, 30: 341-346.

Dechaine, J., Ruan, H. H., Leon, Y. S. and Zou, X. M. (2005). Correlation between earthworms and plant litter decomposition in a tropical wet forest of Puerto Rico. Pedobiologia, 49: 601607.

Deepthi, M. P. and Kathireswari, P. (2016). Earthworm diversity and analysis of soil inhabited by earthworms in Vatakara, Kozhikode, Kerala, India. Int. J. Curr. Microbiol. App. Sci., 5: 917-925.

Fragoso, C., Kanyonyo, J., Moreno, A., Senapati, B. K., Blanchart, E. and 
Rodriguez, C. (1999). A Survey of Tropical Earthworms: Taxonomy, Biogeography and Environmental Plasticity. In: Earthworm Management in Tropical Agroecosystems. (Ed. P. Lavelle, L. Brussaard and P. Hendrix). CAB International, UK.

Jhulka, J. M. (2014). Diversity and distribution of exotic earthworms (Annelida oligochaeta) in India: A Review. In: Biology and Ecology of Tropical Earthworms (ed. P. Chaudhuri and S. M. Singh). DPH Pvt. Ltd., New Delhi.

Larink, O., Werner, D., Langmaack, M. and Schrade, S. (2001). Regeneration of compacted soil aggregates by Earthworm activity. Biol. \& Fert. Soils, 33: 395-401.

Lee, K. E. (1985). Earthworms: Their Ecology and Relationship with Soil and Land Use. Academic Press, Sydeny.

Lewis, T. and Taylor, L. R. (1968). Introduction to Experimental Ecology. New York: Academic Press. p. 401.

Mariappan, V., Karthkairaj, K. and Isaiarasu, L. (2013). Relationship between earthworm abundance and soil quality of different cultivated lands of Rajapalayam, Tamil Nadu. World Appl. Sci. J., 27: 1278-1281.

Parthasarathi, K., Balamurugan, M., Prashija, K. V. and Ameer Basha, S. (2015). Earthworms Population and Community Structure from agroecosystem of Cauvery Delta areas of Tamil Nadu State, India. Blaze. J. Biodivers. Conserv., 1: 1-13.

Rai, S. N. (2017). Earthworm Biodiversity in Different Land Use System. Int. J. Res. Granthaalayah, 5: 347-352.

Reynolds, J. W. (1994). Earthworms of the World. Global Biodiversity, 4: 11-16.

Teng, S. K., Aziz, N. A. A., Anang, N., Mustafa, M., Ismail, A., Yan, Y. W. (2013). Earthworm diversity and population density in Kaki Bukit Agroecosystem, Perlis, Peninsular, Malaysia. Trop. Ecol., 54: 291-299.

Walkley, A. (1947). A critical examination of a rapid method for determination of organic carbon in soils - effect of variations in digestion conditions and of inorganic soil constituents. Soil Sci. 63: 251-257.

\section{How to cite this article:}

Senthil, V. and Sivakami, R. 2018. An Analysis of the Biodiversity of Earthworms in Three Locations around Tiruchirappalli, Tamil Nadu, India. Int.J.Curr.Microbiol.App.Sci. 7(09): 3195-3199. doi: https://doi.org/10.20546/ijcmas.2018.709.397 